\title{
Blijvende gevolgen van een gebrekkige start?
}

\author{
Maarten H.J. Wolbers*
}

\begin{abstract}
In dit artikel wordt onderzocht of een gebrekkige start op de arbeidsmarkt (dat wil zeggen, tijdelijk werk en overscholing in de eerste baan) blijvende, nadelige gevolgen heeft voor de latere arbeidsmarktpositie van individuen in Nederland. De empirische analyse is gebaseerd op gegevens van het Nederlandse deel van het Internationaal Sociaal Survey Programma (ISSP) van 2005 en 2006. De analytische steekproef bevat maximaal 828 respondenten, die het initieel onderwijs hebben verlaten in de periode 1970-2006 en van wie informatie beschikbaar is over baankenmerken van hun eerste en huidige arbeidsmarktpositie. De resultaten suggereren dat een 'slechte' start permanente, negatieve gevolgen heeft voor de latere arbeidsmarktpositie van individuen, daarbij duidelijk steungevend aan de valhypothese. Alleen de bevinding van een afnemend positief effect van tijdelijk werk in de eerste baan op de latere kans om tewerkgesteld te zijn in een tijdelijke baan geeft enige evidentie voor de brughypothese. Tot slot is er enige heterogeniteit gevonden in de effecten van een gebrekkige start met betrekking tot etniciteit en de macro-economische omstandigheden waaronder cohorten de arbeidsmarkt betreden.
\end{abstract}

Trefwoorden: arbeidsmarktintrede, tijdelijk werk, overscholing, huidige arbeidsmarktpositie

\section{Inleiding}

De positie van jongeren op de Nederlandse arbeidsmarkt is aan flinke veranderingen onderhevig geweest sinds de jaren zevenig van de vorige eeuw. Deze veranderingen betreffen niet alleen het werkgelegenheidsperspectief (Salverda, 2003), maar ook de werkzekerheid en kwaliteit van het werk (Wolbers, 2008). Een hoge (jeugd)werkloosheid, met name in het begin van de jaren tachtig, maar ook nu vanwege de recente kredietcrisis, hebben de roep om arbeidsmarktflexibilisering gestimuleerd. Als gevolg daarvan zijn verschillende vormen van flexibele arbeid (zoals tijdelijk werk) opgekomen (Kalleberg, 2000). Daarnaast heeft de globalisering bijgedragen aan de flexibilisering van de arbeidsmarkt (Castells, 2000). Zowel door het verspreiden van informatietechnologie als door reorganisaties van bedrijven is de vraag naar arbeid verschoven van laag- naar hooggeschoold werk. De toename van het aantal hooggekwalificeerde arbeidsplaatsen heeft echter de sterke stijging van het opleidingspeil van de (beroeps)bevolking als gevolg van de onderwijsexpansie niet kunnen compenseren, waardoor een toenemend aantal schoolverlaters terechtkomt in een baan onder hun niveau. De overscholing van (hoogopgeleide) jongeren heeft geleid tot een verdringingsproces, waarbij hoger opgeleiden de posities van lager opgeleiden innemen en laatstgenoemden naar nog lagere posities moeten uitwijken, dan wel werkloos raken (Wolbers, 1998). Met name in $\mathrm{Ne}-$ derland, waar werkgelegenheidsbeschermende wet- en regelgeving voor zittende werknemers strikt is, de vakbeweging nog steeds invloedrijk is en de meeste bedrijfstakken een cao kennen, hebben deze structurele arbeidsmarktontwikkelingen nadelige gevolgen gehad voor jongeren, omdat zij in hun positie als outsiders zonder relevante

* De auteur is werkzaam bij de sectie Sociologie van de Radboud Universiteit Nijmegen.

E-mail: m.wolbers@maw.ru.nl. 
werkervaring wedijveren om de beschikbare banen met zittende werknemers (insiders) (De Vreyer et al., 2000).

Hoewel veel bekend is over de (moeizame) arbeidsmarktintrede van jongeren in Nederland, is er weinig onderzoek verricht naar de gevolgen van een gebrekkige start voor de beroepsloopbaan. Dit artikel voorziet in een opvulling van deze leemte. De aandacht gaat uit naar de vraag of een gebrekkige intrede nadelige gevolgen heeft voor de latere arbeidsmarktpositie van individuen. De focus is gericht op twee aspecten van een gebrekkige start: tijdelijk werk en overscholing in de eerste baan. ${ }^{1}$ Tijdelijk werk en overscholing hoeven daarbij niet per se als negatieve zaken te worden beschouwd. Zo is tijdelijk werk, maar ook een baan onder het eigen opleidingsniveau, vaak te prefereren boven helemaal geen werk. Daarnaast kunnen jongeren vrijwillig kiezen om een dergelijke baan te accepteren, bijvoorbeeld vanwege de aanwezige flexibiliteit en de mogelijkheid tot zelfreflectie (De Jong et al., 2009). Hoewel tijdelijk werk niet hetzelfde is als overscholing, kunnen beide arbeidsmarktposities als niet-optimaal worden beschouwd. Tijdelijk werk is niet optimaal, omdat het jongeren minder zekerheid biedt in hun baan dan degenen met een vaste aanstelling. Overscholing is niet optimaal, omdat de kennis en vaardigheden verkregen in het onderwijs on(der)benut blijven op de werkvloer. De latere arbeidsmarktpositie wordt vastgesteld via de individuele kans op het moment van ondervraging (voor de meesten vele jaren later) in een tijdelijke of overgeschoolde positie werkzaam te zijn, dan wel in het geheel niet te werken (dat wil zeggen, werkloos of inactief te zijn). Er zijn twee contrasterende hypothesen: de val- en brughypothese. De eerstgenoemde hypothese benadrukt de permanente, negatieve gevolgen van een gebrekkige start voor de latere arbeidsmarktpositie van individuen. Overgangen tussen werkloosheid en tijdelijk werk onderstrepen het kwetsbare karakter van de loopbaan van degenen met een gebrekkige start. De andere hypothese legt de nadruk op het tijdelijke karakter van de eerste baan, die als vluchtig en vergankelijk kan worden aangemerkt. Baanmobiliteit kan ertoe leiden dat een initiële misallocatie wordt gecorrigeerd. Voor de empirische analyse wordt gebruikgemaakt van het Nederlandse deel van het Internationaal Sociaal Survey Programma (ISSP) van 2005 en 2006. De analytische steekproef betreft maximaal 828 respondenten, die het initieel onderwijs in de periode 1970-2006 hebben verlaten en van wie informatie beschikbaar is over kenmerken van zowel hun eerste als huidige arbeidsmarktpositie.

\section{Theoretische achtergrond}

\section{Een gebrekkige start: val ...}

Er kan worden voorspeld dat een gebrekkige start op de arbeidsmarkt blijvende, nadelige gevolgen heeft voor de latere arbeidsmarktpositie van individuen (hypothese 1). Maar waarom is dat zo? De theorie van het menselijk kapitaal (Becker, 1964) stelt dat een gebrekkige start negatief uitpakt voor de (verdere) opbouw van menselijk kapitaal. Beroepservaring wordt beschouwd als de belangrijkste manier om menselijk kapitaal op te bouwen tijdens de loopbaan. Ze staat voor de hoeveelheid scholing die vereist is om adequaat te kunnen functioneren op de werkvloer. Werkgevers streven ernaar om de scholingskosten van werknemers zo laag mogelijk te houden en daarom vinden zij individuen met beroepservaring aantrekkelijker dan degenen zonder relevante ervaring, omdat eerstgenoemden over meer (beroeps- of bedrijfs)specifieke kennis en vaardigheden beschikken. Het is volgens deze theorie evident dat een gebrekkige start op de 
arbeidsmarkt de opbouw van menselijk kapitaal ondermijnt, omdat tijdelijk werk vaak leidt tot een verlies aan productieve vaardigheden en een gebrek aan beroepservaring. Er wordt gesteld dat werkgevers overscholing als een compensatie daarvoor gebruiken (Groot \& Maassen van den Brink, 1996). Daarnaast zijn werkgevers terughoudend als het gaat om (scholings)investeringen in werknemers met tijdelijk en/of overgeschoold werk, vanwege de geringere terugverdientijd van deze investeringen als gevolg van het riscio dat zij het bedrijf of organisatie voortijdig verlaten (Psacharapoulos, 1987).

Ook de signaleringstheorie (Spence, 1973) veronderstelt permanente, negatieve effecten van een gebrekkige start op de arbeidsmarkt. Deze theorie benadrukt het belang van signalen, die potentiële werknemers afgeven om het probleem van onvolledige informatie over hun capaciteiten voor werkgevers te helpen oplossen. Wanneer schoolverlaters de arbeidsmarkt betreden, hebben werkgevers geen andere informatie over hun capaciteiten dan de diploma's behaald in het onderwijs en om die reden gebruiken zij deze als voornaamste selectiecriterium. Naarmate de beroepsloopbaan voortschrijdt, kunnen werkgevers hun selectie meer baseren op de arbeidsmarktervaring en voorgeschiedenis van individuen, kenmerken die wellicht een geldiger afspiegeling zijn van wat iemand kan dan diploma's. Met andere woorden: naast opleiding fungeert de arbeidsmarktloopbaan van individuen als een signaal voor hun mogelijke capaciteiten. Werkgevers zijn waarschijnlijk geneigd te denken dat er iets mis is met personen die in een tijdelijke aanstelling of in een baan onder hun niveau zijn gestart (wat betreft kennis en vaardigheden, motivatie enzovoort), wat veroorzaakt dat zij ook in de toekomst in een marginale arbeidsmarktpositie verstrikt blijven. Deze stigmatisering kan ook een invloed hebben op de betrokken personen zelf. De negatieve signalen die zij ontvangen van werknemers, tasten mogelijkerwijs hun (zelf)vertrouwen aan als het gaat om het vinden van een stabiele positie in de (nabije) toekomst.

\section{... of brug?}

Er zijn daarentegen ook theoretische aanknopingspunten, die stellen dat de nadelige gevolgen van een gebrekkige arbeidsmarktintrede verdwijnen tijdens de beroepsloopbaan (hypothese 2). Voor wat betreft overscholing kan deze voorspelling in de eerste plaats worden afgeleid uit de theorie van loopbaanmobiliteit (Sicherman, 1991). Volgens deze theorie is een deel van de opbrengsten van diploma's in de vorm van opwaartse beroepsmobiliteit. Intreders op de arbeidsmarkt kunnen ervoor kiezen een baan onder hun niveau te accepteren als ze denken dat ze daarin relevante kennis en vaardigheden opdoen. Dit verklaart waarom werknemers, die starten in een baan onder hun niveau vaker opwaarts mobiel zijn dan degenen die in een passende baan beginnen. Als gevolg daarvan heeft overscholing bij arbeidsmarktintrede een tijdelijk karakter. Daarnaast is overscholing veelal het resultaat van onvolledige informatie over de feitelijke capaciteiten van werknemers en over de kenmerken van banen die werkgevers aan te bieden hebben (Logan, 1996). Onder andere door baanwisselingen proberen werkenden een betere aansluiting tussen vereiste en behaalde kwalificaties tot stand te brengen. Ook vanuit dit gezichtspunt bezien is overscholing dus een tijdelijk verschijnsel.

Een tweede argument waarin wordt gesteld dat een gebrekkige start op de arbeidsmarkt tijdelijk van aard is, komt voort uit de theorie over interne arbeidsmarkten (Doeringer \& Piore, 1971). In (bedijfs)interne arbeidsmarkten, die onderdeel zijn van het primaire arbeidsmarksegment, starten jonge werknemers in zogenoemde entreebanen. Het 
loopbaanprofiel van hen hangt hier grotendeels af van de vereiste, aanvullende scholing. De initiële opleidingsachtergrond wordt vaak slechts gebruikt als indicatie van hun trainbaarheid (Arrow, 1973), terwijl het verhogen van hun productieve vaardigheden gebeurt via bedrijfsspecifieke scholing. Wanneer jonge werknemers deze scholing hebben voltooid en hebben laten zien dat zij de benodigde vaardigheden succesvol kunnen toepassen op de werkvloer, dan pas wisselen werkgevers deze entreebanen om voor meer stabiele posities. Tijdelijke banen worden hier dus als een verlengde proeftijd gezien. Daarnaast kan worden verwacht dat aanvullende scholing een positieve invloed heeft op bedrijfsinterne, opwaartse mobiliteit, waarmee het negatieve effect van overscholing bij arbeidsmarktintrede tijdens de latere beroepsloopbaan kleiner wordt (Dekker et al., 2002).

\section{Heterogene effecten van een gebrekkige start}

Tot zo ver zijn voor alle individuen gelijke effecten van een gebrekkige intrede op de latere arbeidsmarktpositie verondersteld, terwijl er sprake kan zijn heterogene uitkomsten (Burgess et al., 2003; Gregg, 2001; Steijn et al., 2006). Het is goed mogelijk dat sommige individuen relatief weinig last ondervinden van een gebrekkige start, terwijl voor anderen de nadelige gevolgen van een gebrekkige arbeidsmarktintrede voor de latere beroepsloopbaan veel groter zijn. Vooral vanuit de arbeidsmarktsegmentatietheorie valt dit te begrijpen. Volgens deze theorie kan de arbeidsmarkt worden opgedeeld in twee segmenten: de primaire en de secundaire arbeidsmarkt (Piore, 1975). Op de primaire arbeidsmarkt bevinden zich vooral werknemers met goedbetaalde, vaste banen en (bedrijfsinterne) promotiemogelijkheden. Het gaat hier om de vaste kern van een bedrijf of organisatie die de hoofdactiviteiten uitvoert. Om een plek op de primaire arbeidsmarkt te bemachtigen, zijn veelal beroepsgerichte kennis en vaardigheden (minimaal op het niveau van het middelbaar beroepsonderwijs) vereist. Werkgevers gebruiken opleiding daarbij als een screening device om de vaardigheden van potentiële werknemers in te schatten en zij verlaten zich daarop bij hun aannamebeleid. Op de secundaire arbeidsmarkt gaat het daarentegen met name om werknemers met een tijdelijk dienstverband, zoals uitzendkrachten. Werkgevers maken gebruik van deze externe arbeidskrachten om fluctuaties in de te verrichten arbeid op te vangen. Zodra de productie van het bedrijf inzakt, zijn deze tijdelijke arbeidskrachten overbodig en worden zij ontslagen. Werkgevers zijn dan ook niet geneigd om (veel) te investeren in deze werknemers. Het betreft vaak ondersteunende en tijdelijke werkzaamheden, die weinig formele scholing vereisen. Dit impliceert dat opleiding een tamelijk irrelevant selectiecriterium is voor werkgevers op de secundaire arbeidsmarkt. In plaats daarvan zijn zij aangewezen op de arbeidsgeschiedenis van individuen, die als een direct signaal voor hun productiviteit geldt. Daarom wordt verondersteld dat de nadelige gevolgen van een gebrekkige start groter zijn op de secundaire dan op de primaire arbeidsmarkt, gegeven de sterkere nadruk op de individuele track record in het eerstgenoemde segment. Dit wordt waarschijnlijk nog vergroot door het feit dat er amper mobiliteit is tussen beide arbeidsmarktsegmenten, waardoor schoolverlaters die de secundaire arbeidsmarkt hebben betreden, vaak 'gevangen' komen te zitten in hun tijdelijke en marginale positie en als gevolg daarvan nauwelijks enig perspectief hebben op een betere en meer stabiele arbeidsmarktpositie.

In de empirische analyse van dit artikel is het vanwege databeperkingen helaas niet mogelijk rechtstreeks een onderscheid te maken tussen beide arbeidsmarktsegmenten. 
Zo ontbreekt bijvoorbeeld gedetailleerde informatie over de sector waarin schoolverlaters bij het betreden van de arbeidsmarkt terecht zijn gekomen. Daarom wordt een indirecte strategie gekozen door naar drie specifieke kenmerken van individuen te kijken, die grotendeels bepalen of iemand in het ene of het andere segment werkzaam is. Het eerste kenmerk betreft opleidingsniveau. Zoals hierboven al is aangegeven, veronderstelt de segmentatietheorie dat toegang tot de primaire arbeidsmarkt slechts mogelijk is als individuen beschikken over beroepsgerichte kennis en vaardigheden (minimaal op het niveau van het middelbaar beroepsonderwijs), terwijl het werk op de secundaire arbeidsmarkt vaak ondersteunende en tijdelijke werkzaamheden betreft, die weinig formele scholing vereisen. Op basis hiervan kan worden verwacht dat laagopgeleiden vooral op de secundaire arbeidsmarkt worden aangetroffen. Gegeven de veronderstelling dat werkgevers hier hoofdzakelijk afgaan op de individuele arbeidsgeschiedenis in plaats van kwalificaties om de productiviteit van werknemers in te schatten, kan worden voorspeld dat voor laagopgeleiden de nadelige gevolgen van een gebrekkige start voor de latere arbeidsmarktpositie groter zijn dan voor hoogopgeleiden (hypothese 3a).

Hetzelfde argument kan worden toegepast op verschillen tussen mannen en vrouwen (hypothese 3b) en autochtonen en allochtonen (hypothese 3c). Vrouwen en allochtonen - ongeacht hun opleidingsniveau - worden vaker op de secundaire arbeidsmarkt aangetroffen dan mannen en autochtonen en daarom zijn de nadelige gevolgen van een gebrekkige arbeidsmarktintrede voor de latere loopbaan voor vrouwelijke en allochtone werknemers groter. Daarnaast voorkomen loopbaanonderbrekingen van vrouwen (om te zorgen voor kinderen en het huishouden) en allochtonen (om perioden van (langdurige) werkloosheid te overbruggen) de opbouw van hun menselijk kapitaal, wat voor hen de negatieve gevolgen van een gebrekkige start op de arbeidsmarkt groter maken. Tevens kan (statistische) discriminatie een rol spelen: vooral voor vrouwen en allochtonen kan tijdelijk werk en overscholing bij arbeidsmarktintrede als een negatief signaal over hun verwachte arbeidsproductiviteit worden opgevat door werkgevers.

Naast deze individuele kenmerken, gerelateerd aan een gesegmenteerde arbeidsmarkt, zijn structurele (macro-economische) arbeidsmarktomstandigheden relevant. Schoolverlaters betreden de arbeidsmarkt onder verschillende conjuncturele omstandigheden. Sommige arbeidsmarktcohorten betreden de arbeidsmarkt tijdens een economische recessie, terwijl andere onder een gunstig gesternte hun intrede doen. De verwachting is dat voor individuen uit cohorten die de arbeidsmarkt onder ongunstige macro-economische omstandigheden betreden, een gebrekkige start minder erg is (hypothese 3d). In een dergelijke periode overkomt het je gewoon dat je start in een tijdelijke aanstelling of in een baan onder niveau, net als zovele anderen. Sterker nog, werkgevers kunnen het aanvaarden van een tijdelijke aanstelling of een baan onder niveau bij intrede op de arbeidsmarkt dan mogelijk als een aanwijzing voor motivatie en de bereidheid tot werken zien. Een gebrekkige arbeidsmarktintrede ten tijde van een gunstig economisch klimaat, daarentegen, is veel eerder een negatief signaal voor werkgevers. Hoe kan het dat iemand geen vaste baan heeft, terwijl anderen deze wel hebben gevonden? Of waarom is iemand overgeschoold, terwijl anderen wel bij de opleiding passend werk hebben gevonden? In dergelijke gevallen zijn werkgevers geneigd te denken dat er welhaast iets mis moet zijn met deze individuen en gaan ze hen als zodanig bestempelen. 


\section{Eerder onderzoek}

De meeste studies over de effecten van overscholing op de latere beroepsloopbaan, richten zich op opwaartse beroepsmobiliteit. Sicherman (1991) bevestigde de voorspelling afgeleid uit zijn theorie van loopbaanmobiliteit, dat in de Verenigde Staten overgeschoolde werknemers een grotere waarschijnlijkheid van opwaartse mobiliteit kennen dan niet-overgeschoolde werknemers. Vergelijkbare resultaten voor de Verenigde Staten zijn gevonden door Robst (1995), die overscholing als een tijdelijk verschijnsel bestempelde. Evenzo benadrukten Groot en Maassen van den Brink (2003) het tijdelijke karakter van overscholing voor de Nederlandse situatie. Volgens hun bevindingen is twee vijfde van de overgeschoolde werknemers binnen twee jaar werkzaam op een baan op niveau. Onderzoek uit het Verenigd Koninkrijk, daarentegen, heeft laten zien dat overscholing onder afgestudeerden wel degelijk langetermijngevolgen heeft (Dolton \& Vignoles, 2000). Volgens deze studie is ongeveer een derde van de afgestudeerden, die in een baan onder hun niveau startten, na zes jaar nog steeds overgeschoold. Ook Duits onderzoek suggereert dat overscholing blijvende gevolgen heeft. Volgens Büchel en Mertens (2004) zijn overgeschoolde werknemers minder vaak opwaarts mobiel dan niet-overgeschoolden.

Ten aanzien van tijdelijk werk komt uit bestaand onderzoek naar voren dat een tijdelijke aanstelling bij arbeidsmarktintrede de latere beroepsloopbaan niet benadeelt, ondanks dat tijdelijk werk tijdens de vroege beroepsloopbaan gepaard gaat met meer perioden van werkloosheid (Scherer, 2004). Deze bevindingen hebben betrekking op de situatie in Duitsland, het Verenigd Koninkrijk en Italië. Op overeenkomstige wijze hebben Steijn en anderen (2006) recentelijk de langetermijngevolgen van een gebrekkige start op de arbeidsmarkt voor Nederland onderzocht. Ook zij concludeerden dat individuen die hun loopbaan met een tijdelijke aanstelling startten, een grotere kans hebben om later werkloos te worden. Tegelijkertijd echter vonden zij dat jonge werknemers met een tijdelijke aanstelling vaker opwaarts mobiel zijn. Nog recenter vond Wolbers (2008) vergelijkbare resultaten voor Nederland met betrekking tot werkloosheid: schoolverlaters met een tijdelijk contract hebben een grotere kans om werkloos te worden dan degenen met een vaste aanstelling.

\section{Onderzoeksopzet}

\section{Data}

De empirische analyse van dit artikel is gebaseerd op gegevens van het Internationaal Sociaal Survey Programma (ISSP) van 2005 en 2006. Het ISSP is een jaarlijks opinieonderzoek onder de bevolkingen van meer dan veertig landen over de gehele wereld. In elk van die landen wordt jaarlijks een steekproef van ongeveer 1.000 inwoners schriftelijk ondervraagd over hun opvattingen over wisselende thema's. Voor 2005 was het thema 'Opvattingen over Werk'. Het thema van 2006 was 'Rol van de Overheid'. In elk van de deelnemende landen wordt de internationale, Engelstalige vragenlijst vertaald en aangepast aan de eigen situatie. Om een representatief beeld van de opvattingen te verkrijgen, wordt een toevalssteekproef uit de bevolkingen getrokken. In Nederland gebeurt dit door een toevalstrekking uit een adressenbestand van alle $\mathrm{Ne}$ derlandse woningen. Meer details over de gegevensverzameling zijn te vinden op de 
website van het ISSP (www.issp.org) en die van de Nederlandse coördinator, hoogleraar Sociologie Harry Ganzeboom (home.fsw.vu.nl/HBG.Ganzeboom/ISSP/index.htm).

Hier wordt alleen gebruikgemaakt van de gegevens die in Nederland zijn verzameld. Gegeven de specifieke interesse van de Nederlandse onderzoekers, die betrokken waren bij het ISSP van 2005 en 2006 naar kwesties rondom sociale ongelijkheid en mobiliteit, zijn in deze jaren aanvullende vragen gesteld over verschillende kenmerken van de eerste en huidige (of laatste) arbeidsmarktpositie van individuen. Ook al verwijzen de thema's naar twee afzonderlijke jaren, de dataverzameling van beide thema's vond in 2006 plaats aan de hand van één survey. De respons bedroeg 42\%, wat laag, maar gebruikelijk is voor een schriftelijke vragenlijst. De analytische steekproef bevat maximaal 828 respondenten, die het initieel onderwijs tussen 1970 en 2006 hebben verlaten en op het moment van ondervraging 15-64 jaar waren.

\section{Variabelen}

De focus is gericht op twee aspecten van een gebrekkige arbeidsmarktintrede: tijdelijk werk en overscholing in de eerste baan. ${ }^{2}$ Tijdelijk werk is gedefinieerd op basis van informatie over het type contract van de eerste baan na schoolverlaten. Overscholing is gebaseerd op het verschil tussen het feitelijk behaalde en het formeel vereiste opleidingsniveau in de eerste baan. Als het behaalde opleidingsniveau van individuen hoger is dan het door de werkgever vereiste opleidingsniveau (bepaald aan de hand van een inschating van de respondent), dan is er sprake van overscholing. Zowel het behaalde als vereiste opleidingsniveau is gemeten via een indeling van opleidingen, die loopt van basisonderwijs (bo) tot en met universiteit (wo). ${ }^{3}$ De latere arbeidsmarktpositie is vastgesteld door te vragen naar de situatie op het moment van ondervraging. De volgende categorieën zijn daarbij onderscheiden, opgedeeld in twee afzonderlijke variabelen: (1) inactief, werkloos of tijdelijk werk tegenover vast werk; en (2) inactief, werkloos of overgeschoold tegenover niet-overgeschoold. ${ }^{4}$

Een probleem bij het analyseren van tijdelijk werk en overscholing bij intrede op de latere arbeidsmarktpositie van individuen, is de mogelijke endogeniteit van de eerste baan voor wat betreft latere arbeidsmarktuitkomsten. Waarom hebben sommige schoolverlaters een tijdelijke baan en anderen niet? En waarom zijn sommigen overgeschoold voor hun eerste baan en anderen niet? Het is duidelijk dat hier sprake is van een keuze- of selectieproces. Als jonge werknemers met geringe cognitieve capaciteiten (of een gebrekkige motivatie) een tijdelijke aanstelling hebben of in een baan terechtkomen waarvoor ze zijn overgeschoold, dan zullen zij hier onvermijdelijk lange tijd hinder van ondervinden. Het is in dit geval echter niet de gebrekkige start op de arbeidsmarkt die hen gevangen houdt in een marginale positie, maar hun geringe talenten. Hoewel er meestal geen eenvoudige oplossing voor dit selectieprobleem voorhanden is, wordt een dergelijk veronderstelde vertekening zo goed mogelijk weggenomen door specifieke controlevariabelen in de uit te voeren multivariate analyse op te nemen. ${ }^{5}$

In de eerste plaats wordt rekening gehouden met een aantal achtergrondkenmerken van individuen die grotendeels hun kansen op de arbeidsmarkt bepalen. Een eerste relevant kenmerk is natuurlijk het behaalde opleidingsniveau. Er wordt daarbij de volgende vijfdeling gehanteerd: basisonderwijs of lager voortgezet onderwijs (bo/vmbo), hoger voortgezet onderwijs (havo/vwo), middelbaar beroepsonderwijs (mbo), hoger 
beroepsonderwijs (hbo) en universiteit (wo). Sekserverschillen worden vastgesteld door mannen en vrouwen te onderscheiden. Etniciteit is gebaseerd op informatie over het geboorteland van respondenten en hun ouders. Een allochtoon is iemand die in het buitenland is geboren of van wie ten minste een van de ouders in het buitenland is geboren. Landen die in dit kader als buitenland staan geboekstaafd zijn terug te vinden in de Wet Stimulering Arbeidsdeelname Minderheden (SAMEN).

In de tweede plaats worden de cognitieve capaciteiten van individuen benaderd door hun leerprestaties in het voortgezet onderwijs. Deze prestaties zijn vastgesteld door respondenten te vragen of ze hoge cijfers behaalden in het voortgezet onderwijs ('altijd/ vaak' tegenover 'soms/(bijna) nooit'). ${ }^{6}$

In de derde plaats is een exogene meting van arbeidsmarktomstandigheden gebruikt om het mogelijke endogeniteitsprobleem te omzeilen: het werkloosheidspercentage in het jaar van schoolverlaten. Bovendien is deze variabele in de analyse opgenomen om te bepalen of de invloed van een gebrekkige arbeidsmarktintrede op de latere arbeidsmarktsituatie van individuen verschilt onder wisselende macro-eonomische omstandigheden. De werkloosheidspercentages zijn gebaseerd op cijfers van het Centraal Bureau voor de Statistiek (CBS, 2007) en variëren tussen 0,7\% in 1970 en 10,2\% in de jaren 1983 en 1984.

In de vierde plaats, ten slotte, zijn enkele andere, arbeidsmarktgerelateerde kenmerken opgenomen in de analyse. De duur tot het vinden van de eerste baan is gemeten door de tijdsperiode (in maanden) tussen het moment van schoolverlaten en het tijdstip waarop de eerste baan startte. Degenen die nooit een eerste baan hebben gehad, zijn niet meegenomen in de analyse. Deeltijdwerk en werkzaamheid in de publieke sector zijn twee kenmerken van de eerste baan. Het ene kenmerk verwijst naar de situatie waarin minder dan 33 uur per week wordt gewerkt; het andere betreft degenen die in de publieke sector (overheid, onderwijs, gezondheidszorg en dergelijke) werken. Arbeidsmarktervaring is gedefinieerd als de periode (gemeten in jaren) tussen de start van de eerste baan en het moment van ondervraging. Het betreft dus een maat voor potentiële arbeidsmarktervaring, omdat perioden van inactiviteit of werkloosheid tussen de eerste en huidige arbeidsmarktpositie niet zijn verdisconteerd. ${ }^{7}$ De waarde van deze variabele varieert van 0 tot en met 36 jaar.

\section{Resultaten}

Voordat via multivariate analyse een schatting van de effecten van een gebrekkige start op de latere arbeidsmarktpositie plaatsvindt, wordt de bivariate samenhang tussen tijdelijk werk en overscholing bij arbeidsmarktintrede enerzijds en de latere arbeidsmarktsituatie anderzijds beschreven in tabel 1 . Uit deze tabel komt naar voren dat twee derde van de intreders die startten in een tijdelijke baan tegenwoordig een vaste aanstelling hebben. Dit percentage is aanzienlijk lager in vergelijking met degenen die bij aanvang op de arbeidsmarkt reeds een vaste aanstelling hadden (het verschil bedraagt 14 procentpunten). Omgekeerd zijn individuen die in een tijdelijke baan begonnen, thans vaker in een tijdelijke aanstelling werkzaam dan degenen die in een vaste baan startten (de percentages zijn respectievelijk 18 en 6\%). Ze zijn ook vaker inactief. Als het gaat om werkloosheid, tot slot, zijn de verschillen tussen intreders die wel of niet tijdelijk werk hadden, kleiner. 
Daarnaast laat tabel 1 zien dat de samenhang tussen tijdelijk werk in de eerste en de huidige baan sterk afneemt tijdens de beroepsloopbaan. Binnen de groep van minst ervaren werknemers is de kansverhouding (odds) op tijdelijk tegenover vast werk zeven keer groter voor personen die in een tijdelijke baan startten, dan voor degenen die direct een vaste baan hadden $((27 / 62) /(5 / 80)=7)$. Binnen de groep van werknemers met twintig of meer jaren ervaring is de overeenkomstige odds ratio 2 .

Het percentage individuen, die overgeschoold waren in hun eerste baan, maar tegenwoordig werkzaam zijn op het eigen opleidingsniveau (42\%), is ongeveer even groot als het percentage individuen, die overgeschoold zijn gebleven (43\%). Voor degenen die direct bij aanvang op de arbeidsmarkt al een passende baan hadden, is daarentegen ruim $80 \%$ op het moment van ondervraging werkzaam in een dergelijke baan, tegenover $6 \%$ die van een niet-overgeschoolde naar een overgeschoolde positie is veranderd. Met andere woorden: jonge werknemers, die overgeschoold waren ten tijde van hun arbeidsmarktintrede, hebben een grotere kans om dat tegenwoordig nog steeds te zijn in vergelijking met degenen die in een passende baan begonnen. De odds ratio heeft de waarde 14. Bovendien laten de resultaten zien dat jonge werknemers die als overgeschoold startten, tegenwoordig relatief vaker werkloos zijn.

Net als bij tijdelijk werk zwakt de relatie tussen overscholing in de eerste en huidige baan af tijdens de beroepsloopbaan van individuen, ook al is de afname hier een stuk geringer. Binnen de groep van werknemers, die over minder dan tien jaar arbeidsmarktervaring beschikken, is de kansverhouding op overgeschoold tegenover niet overgeschoold werk maar liefst twintig keer groter voor individuen die overgeschoold waren in hun eerste baan, dan voor degenen die in een bij de opleiding passende baan begonnen. Binnen de groep van meest ervaren werknemers (met twintig of meer jaren ervaring) is de overeenkomstige odds ratio beduidend lager, maar nog steeds aanzienlijk (namelijk 12).

Tabel I De huidige arbeidsmarktpositie van individuen die in hun eerste baan tijdelijk werk hadden en/of overgeschoold waren naar arbeidsmarktervaring: percentages $^{\mathbf{a}}$

\begin{tabular}{|c|c|c|c|c|c|c|}
\hline & \multicolumn{6}{|c|}{ Huidige arbeidsmarktpositie } \\
\hline & Inactief & $\begin{array}{c}\text { Werk- } \\
\text { loos }\end{array}$ & $\begin{array}{r}\text { Tijdelijk } \\
\text { werk }\end{array}$ & $\begin{array}{c}\text { Vast } \\
\text { werk }\end{array}$ & $\begin{array}{l}\text { Overge- } \\
\text { schoold }\end{array}$ & $\begin{array}{l}\text { Niet over- } \\
\text { geschoold }\end{array}$ \\
\hline \multicolumn{7}{|l|}{ Tijdelijk werk in eerste baan } \\
\hline 0-9 jaar arbeidsmarktervaring & $9(11)$ & $2(5)$ & $27(5)$ & $62(80)$ & & \\
\hline 10-19 jaar arbeidsmarktervaring & $19(9)$ & $2(3)$ & $13(6)$ & $67(83)$ & & \\
\hline 20+ jaar arbeidsmarktervaring & $15(9)$ & $4(4)$ & II (6) & $70(80)$ & & \\
\hline Totaal & $13(10)$ & $3(4)$ & $18(6)$ & $66(8 \mathrm{I})$ & & \\
\hline \multicolumn{7}{|l|}{ Overgeschoold in eerste baan } \\
\hline 0-9 jaar arbeidsmarktervaring & $6(14)$ & $6(4)$ & & & $56(7)$ & $33(76)$ \\
\hline 10-19 jaar arbeidsmarktervaring & $10(12)$ & $4(2)$ & & & $34(7)$ & $52(80)$ \\
\hline $20+$ jaar arbeidsmarktervaring & $17(8)$ & $9(2)$ & & & $28(4)$ & $45(85)$ \\
\hline Totaal & $9(11)$ & $6(3)$ & & & $43(6)$ & $42(81)$ \\
\hline
\end{tabular}

a Tussen haakjes staan de overeenkomstige percentages voor degenen die in hun eerste baan vast werk en/ of niet overgeschoold waren.

Bron: Eigen berekeningen op basis van het Nederlandse deel van het ISSP 2005 en 2006. 
De bovengenoemde resultaten worden vervolgens nader geanalyseerd met behulp van multinomiale logistische regressie-analyse. Deze analyse geeft op multivariate wijze de effecten weer van verschillende onafhankelijke variabelen op de kansverhouding inactief, werkloos of tijdelijk werk tegenover vast werk, respectievelijk inactief, werkloos of overgeschoold tegenover niet overgeschoold. Odds ratio's kunnen worden berekend door de antilog te nemen uit de geschatte regressiecoëfficiënten $[\exp (b)]$. Voor elke afhankelijke variabele zijn twee modellen geschat. In het eerste model zijn alle bestudeerde achtergrondkenmerken, arbeidsmarktkenmerken en kenmerken van de eerste baan opgenomen. Het tweede model bevat daarbovenop statistische interactietermen tussen de variabelen tijdelijk werk en overscholing in de eerste baan enerzijds en de kenmerken arbeidsmarktervaring, etniciteit, sekse, opleiding en het werkloosheidscijfer in het jaar van schoolverlaten anderzijds. De statistische interacties met arbeidsmarktervaring geven aan in hoeverre de nadelige gevolgen van een gebrekkige start op de arbeidsmarkt afnemen tijdens de beroepsloopbaan van individuen. De overige interacties tonen in hoeverre de effecten van een gebrekkige start variëren tussen verschillende sociale groepen.

Tabel 2 laat zien dat intreders op de arbeidsmarkt, die startten met tijdelijk werk vaker een tijdelijke aanstelling hebben in hun huidige baan dan degenen die direct met vast werk begonnen. De geschatte odds ratio is ruim $3\left(\mathrm{e}^{1.26}\right)$. Ook met betrekking tot inactiviteit is er een invloed van tijdelijk werk in de eerste baan. Voor jonge werknemers, die bij aanvang op de arbeidsmarkt een tijdelijke aantelling hadden, is de kansverhouding inactief tegenover vast werk twee keer groter dan de overeenkomstige kansverhouding voor degenen met een vaste aanstelling bij arbeidsmarktintrede. Deze resultaten zijn in overeenstemming met hypothese 1 .

Naast de effecten van tijdelijk werk in de eerste baan, beïnvloeden drie achtergrondkenmerken de huidige arbeidsmarktsituatie van individuen. In de eerste plaats zijn allochtonen vaker werkzaam in een tijdelijke baan dan autochtonen. Allochtonen zijn bovendien vaker werkloos. In de tweede plaats nemen vrouwen minder deel aan het arbeidsproces dan mannen. Deze bevinding is vast en zeker gerelateerd aan het verschijnsel dat vrouwen hun arbeidsmarktdeelname veelal combineren met zorgtaken in het gezin. In de derde plaats speelt opleiding een rol bij de huidige arbeidsmarktsituatie van individuen. Degenen met een universitaire graad zijn verrassend genoeg het vaakst werkzaam in een tijdelijke baan op het moment van ondervraging. De bijbehorende odds ratio bedraagt ruim $3\left(\mathrm{e}^{1.23}\right)$. De laagstgekwalificeerden (bo/vmbo) lopen het grootste risico om werkloos te zijn. Afgestudeerden van het hbo zijn het minst vaak inactief.

Arbeidsmarktkenmerken en kenmerken van de eerste baan - naast het effect van tijdelijk werk in de eerste baan natuurlijk - zijn eveneens van belang. Allereerst geldt dat individuen voor wie het geruime tijd duurde voordat zij hun eerste baan bemachtigden, vaker werkloos zijn op het moment van ondervraging dan degenen die snel werk vonden na schoolverlaten. Hoewel een start in werkloosheid niet centraal staat in dit artikel, is het wel een verdere bevestiging van de veronderstelling dat een gebrekkige start nadelige gevolgen heeft voor de latere arbeidsmarktpositie van individuen. Daarnaast heeft het werkloosheidspercentage in het jaar van schoolverlaten vreemd genoeg een negatieve invloed op de kans op inactiviteit. Tot slot zijn individuen die overgeschoold waren in hun eerste baan tegenwoordig vaker werkloos dan degenen die startten in een bij de opleiding passende baan. 
Tabel 2 Resultaten van multinomiale logistische regressie-analyse van de huidige arbeidsmarktpositie (inactief, werkloos of tijdelijk werk tegenover vast werk): logit effecten

\begin{tabular}{|c|c|c|c|c|c|c|}
\hline & \multicolumn{3}{|c|}{ Model I } & \multicolumn{3}{|c|}{ Model 2} \\
\hline & $\begin{array}{l}\text { Inac- } \\
\text { tief a }\end{array}$ & $\begin{array}{c}\text { Werk- } \\
\text { loos }^{\mathrm{a}}\end{array}$ & $\underset{\text { werk }^{\mathbf{a}}}{\text { Tijdelijk }}$ & $\begin{array}{l}\text { Inac- } \\
\text { tief a }\end{array}$ & $\begin{array}{c}\text { Werk- } \\
\text { loos }^{\mathrm{a}}\end{array}$ & $\begin{array}{c}\text { Tijde- } \\
\text { lijk } \\
\text { werk }^{\mathbf{a}}\end{array}$ \\
\hline Intercept & $-2,04 * *$ & $-3,96 * *$ & $-3,00 * *$ & $-1,72 * *$ & $-4,03$ *⿰㇇⿰亅⿱丿丶丶 & $-3,40 * *$ \\
\hline \multicolumn{7}{|l|}{ Achtergrondkenmerken } \\
\hline Allochtoon & 0,22 & $0,94+$ & $1,15 * *$ & 0,43 & $0,93+$ & 0,37 \\
\hline Vrouw & $1,72 * *$ & 0,05 & 0,43 & $1,44 * *$ & $-0,03$ & $0,79+$ \\
\hline \multicolumn{7}{|l|}{ Opleiding } \\
\hline bo/vmbo & $-0,10$ & $1,28 *$ & 0,42 & 0,03 & $1,39 *$ & 0,25 \\
\hline havo/vwo & 0,32 & $-0,05$ & 0,95 & 0,30 & $-0,09$ & $0,97+$ \\
\hline mbo & ref. & ref. & ref. & ref. & ref. & ref. \\
\hline hbo & $-1,13 * *$ & $-0,02$ & 0,59 & $-1,23 * *$ & $-0,07$ & 0,43 \\
\hline wo & $-0,46$ & 0,06 & $1,23 * *$ & $-0,68$ & $-0,13$ & $1,01+$ \\
\hline Hoge cijfers in voortgezet onderwijs & $-0,28$ & 0,42 & $-0,14$ & $-0,26$ & 0,43 & $-0,18$ \\
\hline \multicolumn{7}{|l|}{ Arbeidsmarktkenmerken } \\
\hline Duur tot vinden eerste baan & 0,01 & $0,04 *$ & $-0,02$ & 0,01 & $0,04 *$ & $-0,02$ \\
\hline Werkloosheid jaar van schoolverlaten & $-0,11 *$ & $-0,01$ & $-0,09$ & $-0,12 *$ & 0,01 & $-0,06$ \\
\hline Arbeidsmarktervaring & $-0,01$ & $-0,02$ & 0,00 & $-0,02$ & $-0,02$ & 0,03 \\
\hline \multicolumn{7}{|l|}{ Kenmerken eerste baan } \\
\hline Tijdelijk werk & $0,74 *$ & $-0,95$ & $1,26 * *$ & $-3,74$ & $-2,56$ & $-0,27$ \\
\hline Overgeschoold & $-0,02$ & $1,03 *$ & $-0,03$ & 0,01 & $\mathrm{I}, \mathrm{II} *$ & $-0,14$ \\
\hline Deeltijdwerk & $-0,46$ & $-0,20$ & $-0,17$ & $-0,44$ & $-0,23$ & $-0,51$ \\
\hline Werkzaam in publieke sector & $-0,16$ & 0,14 & $-0,14$ & $-0,15$ & 0,15 & $-0,14$ \\
\hline \multicolumn{7}{|l|}{ Interacties met tijdelijk werk } \\
\hline Arbeidsmarktervaring & & & & 0,04 & 0,03 & $-0,09 *$ \\
\hline Allochtoon & & & & -- & $-0,12$ & $1,99 *$ \\
\hline Vrouw & & & & 2,02 & 1,08 & $-0,79$ \\
\hline Opleiding ${ }^{\mathrm{b}}$ & & & & 0,13 & 0,18 & 0,14 \\
\hline Werkloosheid jaar van schoolverlaten & & & & 0,05 & $-0,40$ & 0,06 \\
\hline Model $\mathrm{Chi}^{2}$ & & $121 * *$ & & & $150 * *$ & \\
\hline Df & & 42 & & & 57 & \\
\hline $\mathrm{N}$ & & 828 & & & 828 & \\
\hline
\end{tabular}

** Effect significant bij $\mathrm{p}<0,01$; * effect significant bij $\mathrm{p}<0,05 ;+$ effect significant bij $\mathrm{p}<0,10$.

a Ten opzichte van vast werk.

b Opleiding is hier als continue variabele beschouwd (in termen van jaren onderwijs) varierënd van 6 jaar (voor bo) tot en met 20 jaar (voor wo).

-- Coefficiënt is niet betrouwbaar vanwege gering aantal waarnemingen en daarom niet weergegeven.

Bron: Eigen berekeningen op basis van het Nederlandse deel van het ISSP 2005 en 2006.

In model 2 zijn, zoals gezegd, statistische interactietermen opgenomen. De resultaten van dit model laten steun zien voor de voorspelling dat de invloed van tijdelijk werk bij aanvang op de arbeidsmarkt op de huidige kans om in een tijdelijke aanstelling werkzaam te zijn, afneemt gedurende de beroepsloopbaan (zie hypothese 2). Na ongeveer 25 jaar arbeidsmarktervaring is het initiële effect volledig verdwenen. ${ }^{8}$ Daarnaast is de invloed van tijdelijk werk in de eerste baan op de kans om in de huidige baan tijdelijk werk te hebben, aanzienlijk groter voor autochtonen dan allochtonen. Het betreffende interactie-effect bedraagt 1,99. Deze bevinding komt overeen met hypothese $3 c$. Voor de hypothesen $3 \mathrm{a}, 3 \mathrm{~b}$ en $3 \mathrm{~d}$ is geen steun gevonden. 
Tabel 3 laat zien dat overscholing in de eerste baan de latere arbeidsmarktpositie negatief beïnvloedt. Volgens model 1 zijn jonge werknemers die overgeschoold waren bij intrede op de arbeidsmarkt vaker overgeschoold, werkloos of inactief op het moment van ondervraging dan degenen die in een niet overgeschoolde positie startten. Het effect is het sterkst bij de kans op overscholing. Voor personen die overgeschoold waren in hun eerste baan is de kansverhouding op overgeschoold tegenover niet-overgeschoold werk in de huidige baan meer dan $10\left(\mathrm{e}^{2.35}\right)$ keer groter dan de overeenkomstige kansverhouding voor degenen die een bij de opleiding passende baan hadden bij aanvang op de arbeidsmarkt. Voor wat betreft de huidige kans op werkloosheid en inactiviteit bedragen de odds ratio's respectievelijk bijna 5 en bijna 2. Deze bevindingen zijn opnieuw niet in strijd met hypothese 1 .

Daarnaast zijn enkele achtergrondkenmerken, arbeidsmarktkenmerken en kenmerken van de eerste baan relevant. Omdat de resultaten met betrekking tot de huidige kans op werkloosheid en inactiviteit in tabel 3 sterk lijken op de resultaten zoals gepresenteerd in tabel 2, worden hier alleen de significante effecten op de huidige kans op overscholing besproken. Ten eerste blijkt dat allochtonen vaker werkzaam zijn in een baan waarvoor ze zijn overgeschoold dan autochtonen. Ten tweede komt naar voren dat hoogopgeleiden vaker overgeschoold zijn dan laagopgeleiden. Ten derde spelen cognitieve capaciteiten een rol bij het voorkomen van overscholing. Werkenden die altijd of vaak hoge cijfers behaalden in het voortgezet onderwijs, zijn minder vaak overgeschoold in hun huidige baan dan degenen die dat soms of (bijna) nooit deden. Ten vierde zijn meer ervaren werknemers minder vaak overgeschoold in hun huidige baan dan minder ervaren werknemers. Ten vijfde zijn werkenden die in een deeltijdbaan startten vaker overgeschoold in hun huidige baan dan degenen die in een voltijdbaan aanvingen. Tot slotte zijn werknemers van wie hun eerste baan in de publieke sector was, minder vaak overgeschoold dan degenen die hun loopbaan startten in de private sector. Zoals gezegd, omvat de publieke sector onder meer al het werk in het onderwijs en de gezondheidszorg. Kenmerkende beroepen in deze werkvelden zijn leerkracht en arts, die alleen toegankelijk zijn wanneer men beschikt over de vereiste diploma's.

In model 2 zijn opnieuw statistische interacties getoetst. De resultaten van dit model laten allereerst zien dat de nadelige effecten van overscholing in de eerste baan op de huidige kans op overscholing en werkloosheid geringer zijn voor allochtonen dan voor autochtonen. Deze bevindingen weerspreken hypothese $3 c$. In de tweede plaats toont model 2 dat de effecten van overscholing bij arbeidsmarktintrede op de huidige kans op overscholing en werkloosheid kleiner zijn in tijden van hoge werkloosheid dan in tijden van lage werkloosheid. Deze resultaten zijn in lijn met hypothese 3d. De hypothesen 2, 3a en $3 \mathrm{~b}$ worden niet ondersteund door de data. 
Tabel 3 Resultaten van multinomiale logistische regressie-analyse van de huidige arbeidsmarktpositie (inactief, werkloos of overgeschoold tegenover niet overgeschoold): logit effecten

\begin{tabular}{|c|c|c|c|c|c|c|}
\hline \multirow{3}{*}{ Intercept } & \multicolumn{3}{|c|}{ Model I } & \multicolumn{3}{|c|}{ Model 2} \\
\hline & $\begin{array}{l}\text { Inac- } \\
\text { tief a }\end{array}$ & $\begin{array}{l}\text { Werk- } \\
\text { loos }^{\mathbf{a}}\end{array}$ & $\begin{array}{l}\text { Overge- } \\
\text { schoold }\end{array}$ & $\begin{array}{l}\text { Inac- } \\
\text { tief a }\end{array}$ & $\begin{array}{l}\text { Werk- } \\
\text { loos }^{\mathrm{a}}\end{array}$ & $\begin{array}{l}\text { Overge- } \\
\text { schoold }\end{array}$ \\
\hline & $-1,91 * *$ & $-3,73 * *$ & $-1,68$ ** & $-1,72$ ** & $-4,64$ *⿰㇇⿰亅⿱丿丶丶 & $-3,03 * *$ \\
\hline \multicolumn{7}{|l|}{ Achtergrondkenmerken } \\
\hline Allochtoon & 0,36 & $1,13 *$ & $0,77 *$ & 0,17 & $2,03 * *$ & $1,60 * *$ \\
\hline Vrouw & $1,74 * *$ & 0,11 & 0,31 & $1,50 * *$ & $-0,52$ & 0,34 \\
\hline \multicolumn{7}{|l|}{ Opleiding } \\
\hline bo/vmbo & $-0,24$ & $1,08+$ & $-1,66 * *$ & $-0,10$ & $1,15+$ & $-1,95 * *$ \\
\hline havo/vwo & 0,19 & $-0,12$ & $-0,15$ & 0,13 & 0,12 & $-0,08$ \\
\hline mbo & ref. & ref. & ref. & ref. & ref. & ref. \\
\hline hbo & $-1,15 * *$ & $-0,07$ & $-0,06$ & $-1,03 *$ & $-0,12$ & 0,18 \\
\hline wo & $-0,18$ & 0,40 & 1,12 ** & $-0,10$ & 0,46 & $1,50 * *$ \\
\hline Hoge cijfers in voortgezet onderwijs & $-0,35$ & 0,32 & $-0,52 *$ & $-0,37$ & 0,21 & $-0,50 *$ \\
\hline \multicolumn{7}{|l|}{ Arbeidsmarktkenmerken } \\
\hline Duur tot vinden eerste baan & 0,01 & $0,04+$ & $-0,01$ & 0,01 & $0,05+$ & $-0,01$ \\
\hline Werkloosheid jaar van schoolverlaten & $-0,11 *$ & $-0,02$ & $-0,07$ & $-0,09$ & 0,18 & 0,03 \\
\hline Arbeidsmarktervaring & $-0,02$ & $-0,02$ & $-0,02+$ & $-0,03$ & $-0,04$ & 0,01 \\
\hline \multicolumn{7}{|l|}{ Kenmerken eerste baan } \\
\hline Tijdelijk werk & $0,57+$ & $-1,15$ & $-0,13$ & $0,60+$ & $-0,87$ & $-0,07$ \\
\hline Overgeschoold & $0,56+$ & $1,54 * *$ & $2,35 * *$ & $-0,93$ & 0,61 & $3,28 * *$ \\
\hline Deeltijdwerk & $-0,31$ & $-0,02$ & $0,61 *$ & $-0,24$ & 0,06 & $0,54+$ \\
\hline Werkzaam in publieke sector & $-0,28$ & 0,00 & $-0,56 *$ & $-0,30$ & 0,06 & $-0,59 *$ \\
\hline \multicolumn{7}{|l|}{ Interacties met overgeschoold } \\
\hline Arbeidsmarktervaring & & & & 0,05 & 0,05 & $-0,04$ \\
\hline Allochtoon & & & & 0,30 & $-2,74+$ & $-1,33+$ \\
\hline Vrouw & & & & 1,09 & 1,29 & 0,06 \\
\hline Opleidingb & & & & $-0,04$ & 0,00 & $-0,12$ \\
\hline Werkloosheid jaar van schoolverlaten & & & & $-0,11$ & $-0,45 * *$ & $-0,18+$ \\
\hline Model Chi2 & & 316 ** & & & $347 * *$ & \\
\hline Df & & 42 & & & 57 & \\
\hline $\mathrm{N}$ & & 817 & & & 817 & \\
\hline
\end{tabular}

** Effect significant bij $\mathrm{P}<0,0 \mathrm{I}$; * effect significant bij $\mathrm{P}<0,05 ;+$ effect significant bij $\mathrm{P}<0,10$.

a Ten opzichte van niet overgeschoold.

b Opleiding is hier als continue variabele beschouwd (in termen van jaren onderwijs) varierënd van 6 jaar (voor bo) tot en met 20 jaar (voor wo).

Bron: Eigen berekeningen op basis van het Nederlandse deel van het ISSP 2005 en 2006.

\section{Conclusies en discussie}

Uit de resultaten van dit artikel is allereerst gebleken dat jongeren in Nederland, die startten in een tijdelijke baan, later ook vaker tijdelijk werk hebben of vaker inactief zijn dan degenen die direct bij arbeidsmarktintrede in een vaste baan begonnen. De invloed van tijdelijk werk in de eerste baan op de latere kans op tijdelijk werk neemt echter geleidelijk af gedurenende de beroepsloopbaan en is uitgedoofd na 25 jaar werkervaring. Bovendien is de invloed van tijdelijk werk in de eerste baan op de latere kans in een tijdelijke baan werkzaam te zijn groter voor allochtonen dan autochtonen. 
Daarnaast hebben de bevindingen aangetoond dat jonge werknemers, die in hun eerste baan overgeschoold waren, op het moment van ondervraging ook vaker overgeschoold zijn, werkloos zijn, of inactief zijn dan degenen die bij intrede op de arbeidsmarkt passend werk deden. De effecten van overscholing bij arbeidsmarktintrede op de latere kans op overscholing en werkloosheid zijn daarbij kleiner voor allochtonen dan autochtonen en zwakker in tijden van hoge werkloosheid dan in tijden van lage werkloosheid. Deze laatste bevinding suggereert dat schoolverlaters, die in een periode van laagconjunctuur onder hun niveau startten, dit via opwaartse mobiliteit tijdens de beroepsloopbaan (deels) hebben weten goed te maken.

Over het algemeen bevestigen deze resultaten dus de valhypothese. Ze laten zien dat een gebrekkige start bij intrede langdurige, negatieve gevolgen heeft voor de latere arbeidsmarktpositie van individuen. Alleen de bevinding van een afnemende invloed van tijdelijk werk bij intrede op de arbeidsmarkt op de latere kans op tijdelijk werk verschaft enige steun voor de brughypothese, ook al is het gevonden effect pas in de tweede helft van de beroepsloopbaan volledig verdwenen. Daarnaast is er enige steun gevonden voor de voorspelde heterogeniteit in de effecten van een gebrekkige start op de arbeidsmarkt als het gaat om de rol van etniciteit en macro-economische omstandigheden ten tijde van arbeidsmarktintrede.

Er zijn twee kwesties die meer aandacht behoeven. In de eerste plaats is het de vraag wat de langetermijngevolgen van overscholing bij arbeidsmarktintrede nu precies betekenen. Het kan best zijn dat er - ondanks het blijvende overscholingseffect - sprake is van een efficiënte allocatie van werknemers en banen. Dit is het geval wanneer het bereikte opleidingsniveau geen correcte indicatie is van de werkelijke capaciteiten van werknemers. Met name in de credentialistische visie op het onderwijs (Collins, 1979) wordt gesuggereerd dat men op school geen productieve vaardigheden aanleert - zoals de theorie van het menselijk kapitaal veronderstelt -, maar pas daarna op de werkvloer. In plaats daarvan wordt onderwijs gezien als een goed waaraan status wordt ontleend. De statusaspecten van het onderwijs vormen een belangrijk selectiecriterium van werkgevers en degenen, die over een hoge opleiding beschikken, hebben uitzicht op een goede en stabiele arbeidsmarktpositie. Met andere woorden: overscholing is niet per se gelijk aan onderbenutting, waardoor het blijvende karakter van overscholing geen reëel probleem hoeft te zijn. Dit neemt echter niet weg dat er dan - vanuit het oogpunt van macrodoelmatigheid - sprake is van een overinvestering in het volgen van onderwijs door individuen.

In de tweede plaats is in dit artikel een statische en beperkte blik op de latere arbeidsmarktpositie van individuen geworpen door de situatie op het moment van ondervraging te bestuderen, terwijl duidelijk is dat een dynamisch perspectief nodig is om individuele carrières te analyseren. De gebruikte gegevens echter bevatten niet meer loopbaangegevens dan informatie over de eerste en de huidige arbeidsmarktpositie van individuen. Voor toekomstig onderzoek naar de blijvende, negatieve gevolgen van een gebrekkige start op de arbeidsmarkt voor de verdere beroepsloopbaan van individuen is het daarom van belang dat longitudinale (retrospectieve levensloop- of prospectieve panel)gegevens worden gebruikt, die door middel van geavanceerde regressietechnieken als gebeurtenissenanalyse dienen te worden geanalyseerd.

Gezien de bevindingen zijn de aanbevelingen voor het beleid duidelijk. Ze suggereren dat vermeden moet worden dat jongeren bij het betreden van de arbeidsmarkt in een 
precaire arbeidsmarktpositie terechtkomen, die stigmatiserend werkt en ertoe leidt dat zij langdurig in een marginale positie verstrikt raken. In het verleden gedane inspanningen als het Jeugd Werk Garantieplan (JWG) en meer recent de Taskforce Jeugdwerkloosheid, in combinatie met het streven van het huidige kabinet om de jaarlijkse nieuwe voortijdige schooluitval met de helft terug te dringen in 2012, blijven cruciaal als het gaat om het voorkomen van het ontstaan van een 'verloren generatie' van jongeren op de Nederlandse arbeidsmarkt.

\section{Noten}

1 De wellicht meest gebrekkige start die individuen kunnen maken op de arbeidsmarkt, is een start in werkloosheid. Dit artikel richt zich echter op een vergelijking tussen kenmerken van de eerste baan en de latere arbeidsmarktpositie van individuen, waarbij overigens wel de duur van een eventuele periode van werkloosheid voor het vinden van de eerste baan na schoolverlaten als (controle)variabele in de multivariate analyse is opgenomen.

2 Beide kenmerken van een gebrekkige start zijn als aparte dimensies te beschouwen. De onderlinge samenhang is zeer gering. De Pearson correlatiecoëfficiënt bedraagt slechts 0,08 .

3 Het is waarschijnlijk dat de retrospectief verzamelde informatie over de eerste baan enigszins vertekend is (De Vries \& De Graaf, 2008). Desondanks is het de meest gangbare manier om beroepsinformatie te verzamelen in onderzoek naar sociale ongelijkheid en mobiliteit. De voorkeur voor retrospectieve dataverzameling is begrijpelijk, omdat prospectieve panelstudies voor dit onderzoeksterrein als nadeel hebben dat het erg lang duurt voordat loopbanen kunnen worden geanalyseerd, paneluitval over een lange periode van dataverzameling groot is en historische vergelijkingen alleen mogelijk zijn wanneer het panel (voor nieuwe cohorten) wordt herhaald.

4 Hoewel voor inactiviteit en werkloosheid als mogelijke gevolgen van tijdelijk werk en overscholing bij aanvang op de arbeidsmarkt geen theoretische rechtvaardiging is gegeven, worden beide vormen van niet-werkzaamheid als categorieën opgenomen in de afhankelijke variabelen. In hoofdzaak gebeurt dit om meer onderscheidend vermogen te hebben in de multivariate analyse.

5 Econometristen verkiezen vaak een Heckman tweestapsprocedure voor deze problematiek (Heckman, 1979). Daarvan is in dit artikel bewust geen gebruik gemaakt. Het nadeel van deze procedure is dat deze alleen betrouwbaardere schattingen oplevert wanneer er een goede (dat wil zeggen, volledig exogene) correctie- of instrumentele variabele aanwezig is in de data, wat meestal niet het geval is. Bovendien is de Heckman tweestapsprocedure niet geschikt voor een multinomiaal logitmodel. Nu zijn er inmiddels wel alternatieve correcties voor selectiebias voorhanden, die gebaseerd zijn op maximum likelihood procedures (Maddala, 1983), maar daar is gespecialiseerde programmatuur voor nodig.

6 Ook hier kan de betrouwbaarheid van de beantwoording in het geding zijn: (oudere) mensen weten wellicht niet meer precies hoe goed hun leerprestaties in het voortgezet onderwijs waren.

7 Voor vrouwen is deze maat voor arbeidsmarktervaring wat problematisch, gezien het feit dat zij hun loopbaan vaak onderbreken en/of in deeltijd werken (met name vanwege het krijgen van kinderen). Helaas is geen betere meting van arbeidsmarktervaring voorhanden in de gebruikte gegevens.

8 De berekeningen zijn gebaseerd op een niet-gepresenteerd model waarin alleen de interactieterm tussen de variabelen tijdelijk werk in de eerste baan en arbeidsmarktervaring is opgenomen. In dit model is het hoofdeffect van tijdelijk werk 2,48 en het interactie-effect met arbeidsmarktervaring 0,10. Dit betekent dat het initiële effect van tijdelijk werk na 25 (2,48 / $0,10)$ jaar arbeidsmarktervaring is uitgedoofd.

\section{Literatuur}

Arrow, K. (1973). Higher education as a filter. Journal of Public Economics, 2, 193-216. 
Becker, G. (1964). Human capital. A theoretical and empirical analysis, with special reference to education. New York: National Bureau of Economic Research.

Büchel, F. \& Mertens, A. (2004). Overeducation, undereducation, and the theory of career mobility. Applied Economics, 36, 803-816.

Burgess, S., Propper, C., Rees, H. \& Shearer, A. (2003). The class of 1981: the effects of early career unemployment on subsequent unemployment experiences. Labour Economics, 10, 291-309.

Castells, M. (2000). The rise of the network society. The information age. Oxford: Blackwell Publishers.

Collins, R. (1979). The credential society. A historical sociology of education and stratification. New York: Academic Press.

CBS (2007). Tijdreeks beroepsbevolking naar geslacht. Geraadpleegd op http://statline.cbs.nl, 16 maart 2007. Voorburg/Heerlen: Centraal Bureau voor de Statistiek.

Dekker, R., Grip, A. de \& Heijke, H. (2002). The effects of training and overeducation on career mobility in a segmented labour market. International Journal of Manpower, 23, 106-125.

Doeringer, P. \& Piore, M. (1971). Internal labor markets and manpower analysis. Lexington, MA: Heath.

Dolton, P. \& Vignoles, A. (2000). The incidence and effects of overeducation in the UK graduate labour market. Economics of Education Review, 19, 179-198.

Gregg, P. (2001). The impact of youth unemployment on adult unemployment in the NCDS. The Economic Journal, 111, F626-F653.

Groot, W. \& Maassen van den Brink, H. (1996). Overscholing en verdringing op de arbeidsmarkt. Economisch Statistische Berichten, 81, 74-77.

Groot, W. \& Maassen van den Brink, H. (2003). The dynamics of skill mismatches in the Dutch labour market. In F. Büchel, A. de Grip \& A. Mertens (red.), Overeducation in Europe: current issues in theory and policy (pp. 49-63). Cheltenham: Edward Elgar.

Heckman, J. (1979). Sample selection bias as a specification error. Econometrica, 51, 153-161.

Jong, J. de, Cuyper, N. De, Witte, H. De, Silla, I. \& Bernhard-Oettel, C. (2009). Motives for accepting temporary employment: A typology. International Journal of Manpower, 30, 237-252.

Kalleberg, A. (2000). Nonstandard employment relations: Part-time, temporary and contract work. Annual Review of Sociology, 26, 341-365.

Logan, J. (1996). Opportunity and choice in socially structured labor markets. American Journal of Sociology, 101, 114-160.

Maddala, G.S. (1983). Limited dependent and qualitative variables in econometrics. Cambridge: Cambridge University Press.

Piore, M. (1975). Notes for a theory of labor market stratification. In R. Edwards, M. Reich \& D. Gordon (eds.), Labor market segmentation (pp. 125-150). London: Lexington Books.

Psacharapoulos, G. (1987). The cost-benefit model. In G. Psacharapoulos (eds.), Economics of education: Research and studies (pp. 342-347). Oxford: Pergamon Press.

Robst, J. (1995). Career mobility, job match, and overeducation. Eastern Economic Journal, 21, 539-550.

Salverda, W. (2003). Jeugdwerkloosheid revisited: terug naar de jaren tachtig? Tijdschrift voor Arbeidsvraagstukken, 19, 332-349.

Scherer, S. (2004). Stepping-stones or traps? The consequences of labour market entry positions on future career in West Germany, Great Britain and Italy. Work, Employment and Society, 18, 369-394.

Sicherman, N. (1991). 'Overeducation' in the labor market. Journal of Labor Economics, 9, 101122.

Spence, M. (1973). Job market signaling. Quarterly Journal of Economics, 87, 355-374.

Steijn, B., Need, A. \& Gesthuizen, M. (2006). Well begun, half done? Long-term effects of labour market entry in the Netherlands, 1950-2000. Work, Employment and Society, 20, 453-472.

Vreyer, Ph. De, Layte, R., Wolbers, M.H.J. \& Hussain, M. (2000). The permanent effects of labour market entry in times of high unemployment. In D. Gallie \& S. Paugam (eds.), Welfare regimes and the experience of unemployment in Europe (pp. 134-152). Oxford: Oxford University Press.

Vries, J. de \& Graaf, P. de (2008). The reliability of family background effects on status attainment: Multiple informant models. Quality and Quantity, 42, 203-234.

Wolbers, M.H.J. (1998). Diploma-inflatie en verdringing op de arbeidsmarkt. Een studie naar ontwikkelingen in de opbrengsten van diploma's in Nederland. Nijmegen: dissertatie Katholieke Universiteit Nijmegen. 
Wolbers, M.H.J. (2008). Increasing labor market instability among young people? Labor market entry and early career development among school-leavers in the Netherlands since the mid1980s. In H.-P. Blossfeld, S. Bucholz, E. Bukodi \& K. Kurz (eds.), Young workers, globalization and the labor market: Comparing early working life in eleven countries (pp. 77-101). Cheltenham, UK/Northampton, MA, USA: Edward Elgar. 